\title{
Mononuclear Cell Count
}

National Cancer Institute

\section{Source}

National Cancer Institute. Mononuclear Cell Count. NCI Thesaurus. Code C154757.

The determination of the amount of mononuclear cells present in a sample. 